\title{
International study on Artemia. LXII. Genomic relationships between Artemia franciscana and $A$. persimilis, inferred from chromocentre numbers
}

\author{
GONZALO GAJARDO*†, JOHN A. BEARDMORE $\uparrow \&$ PATRICK SORGELOOS§ \\ $\dagger$ Laboratory of Genetics \& Aquaculture, Universidad de Los Lagos, PO Box 933, Osorno, Chile, $₫$ School of Biological \\ Sciences, University of Wales Swansea, Singleton Park, Swansea, SA2 8PP, Wales, U.K. and §Laboratory of \\ Aquaculture \& Artemia Reference Centre, University of Ghent, Rozier 44, B-9000, Ghent, Belgium
}

\begin{abstract}
Chromocentres, i.e. heavily stainable heterochromatic areas with highly repetitive DNA (a 130-bp repeat in the order of $6 \times 10^{5}$ copies per haploid genome) observed in the resting nucleus, are a reliable taxonomic trait and a good marker for speciation in Artemia. This chromosome marker was evaluated in populations of two New World sibling species: A. franciscana, from North, Central and South America, and A persimilis from Argentina. Artemia persimilis showed the characteristically low average chromocentre numbers $(<3)$ of the ancestral Mediterranean species, whilst higher numbers ( $>5$ ) were seen in $A$. franciscana. The increase in chromocentre numbers from $A$. persimilis to $A$. franciscana occurred in a rather steady, continuous geographical pattern with an overlapping zone between both species. A north-south steady latitudinal decline of chomocentres was observed towards the equator in $A$. franciscana populations from the northern hemisphere, whilst the trait increased from this point towards southern latitudes with a population in Chilean Patagonia (below $52^{\circ} \mathrm{S}$ ) exhibiting the highest chromocentre frequency. Since chromocentres are positively correlated with repetitive DNA content, differentiation between the species through the amplification of heterochromatin or an increased DNA content in A. franciscana (although this species has a lower diploid chromosome number), might nevertheless reflect chromosomal reorganizations between the species. Chromocentres, together with other traits, reveal a probable hybrid zone between the two species in Chilean Patagonia.
\end{abstract}

Keywords: Artemia, chromocentre, genomic relationship, heterochromatin.

\section{Introduction}

The brine shrimp Artemia (Crustacea, Anostraca) represents a highly favourable system for evolutionary studies, as key elements driving speciation in other organisms can be observed in Artemia; for example, ecological isolation, adaptive switches in reproductive mode dependent on environmental conditions (oviparity vs. ovoviviparity), highly subdivided allopatric populations resulting from the development of local adaptations and large genetic distances between populations. (Abreu-Grobois \& Beardmore, 1982; Abreu-Grobois, 1987; Browne \& Bowen, 1991; Beardmore \& AbreuGrobois, 1983). Additionally, the easy transportation of cysts and the cultivation of populations under laboratory conditions have permitted broad interpopulation

*Correspondence. E-mail: ggajardo@ulagos.cl comparisons. Nevertheless, little is as yet known of the genomic changes underlying speciation in Artemia, particularly in the New World species.

The genus Artemia (Crustacea, Anostraca), distributed in hypersaline environments in all continents except the Antarctic (Triantaphyllidis et al., 1998), is a complex of eight bisexual species and many parthenogenetic types (Browne \& Bowen, 1991). Although in the Old World both bisexual and parthenogenetic populations exist, only two bisexual species have been described for the New World, namely Artemia persimilis (Piccinelli and Prosdocimi) and A. franciscana (Kellogg). The latter is widely distributed in North, Central and South America and represents the most intensively studied species, whereas $A$. persimilis is often referred to as a narrowly distributed species, restricted to Argentina (Abreu-Grobois \& Beardmore, 1982; Abreu-Grobois, 1987; Gajardo \& Beardmore, 1993; Cohen et al., 1999). 
Nevertheless, this view has been challenged recently as the species has been found in Chilean Patagonia (Gajardo et al., 1998; Gajardo et al., 1999; De los Rios \& Zuñiga, 2000).

Artemia persimilis is thought to be closely related to the original group of species which evolved in the Mediterranean area, from which A. franciscana is also derived (Abreu-Grobois, 1987; Badaracco et al., 1987; Browne \& Bowen, 1991). Following a colonization event by a small founder population, $A$. persimilis would have evolved in the New World in geographical isolation from A. franciscana (Abreu-Grobois, 1987). The two species differ by one pair of chromosomes $(2 n=44$ and 42 for A. persimilis and A. franciscana, respectively), by a higher number of chromocentres with highly repetitive DNA in A. franciscana and by a genetic distance value (Nei, 1978) $(D>0.5)$ that is higher than the mean described for conspecific comparisons $(D=0.109)$ (Abreu-Grobois, 1987; Gajardo et al., 1999). Despite these genetic differences, the two species are described as being morphologically very similar (Browne \& Bowen, 1991), though this is not always the case (Gajardo et al., 1998).

Chromocentres are heavily stained heterochromatic areas in interphase nuclei containing a highly repetitive DNA family of the type Alu I (also named satellite I DNA), i.e. a 113-bp sequence repeated in the order of $6 \times 10^{5}$ copies per haploid genome of $A$. franciscana (Barigozzi et al., 1987). This genomic trait varies between and within species, and is correlated to some extent with the genetic differentiation measured by Nei's distances using allozyme data (Abreu-Grobois \& Beardmore, 1982; Colihueque \& Gajardo, 1996), as well as with the amount of repetitive DNA and chromocentre numbers. For example, A. franciscana shows the highest concentration of repetitive DNA and also shows the highest chromocentre frequency (Badaracco et al., 1987).

This work compares chromocentre numbers in samples of $A$. franciscana from North, Central and South America, and samples of $A$. persimilis from Argentina. A comprehensive population survey over a considerable latitudinal range is expected to shed light on the relevance of this chromosome marker to the understanding of intraspecific genetic differentiation and of divergence between sibling Artemia species.

\section{Materials and methods}

The Artemia samples used for the study are from various locations in North, Central and South America (Table 1). Most were obtained from the cyst bank of the Artemia Reference Centre, others were kindly provided as cysts by individuals, as acknowledged in Table 1, while the Chilean populations are from laboratory cultures founded by live wild animals. Cytogenetic data for the Chilean populations (using a non-fluorescent dye, as in this paper) and a detailed protocol for the squash method, have been published elsewhere (Colihueque \& Gajardo, 1996). Briefly, the methodology uses $12-24 \mathrm{~h}$ nauplii $\left(25^{\circ} \mathrm{C}\right)$ obtained either from newly hatched cysts or from cultures maintained in the laboratory. Initial colchicine treatment in sea water for $45 \mathrm{~min}(0.1 \%)$, was followed by thermal shock $\left(42^{\circ} \mathrm{C}\right)$, hypotonic treatment in warm distilled water $\left(38^{\circ} \mathrm{C}\right)$ for $90 \mathrm{~min}$ and fixation in acetic acid $(50 \%)$ for $15 \mathrm{~min}$. After squashing, nauplii were subjected to a Hoesch (pH 5.5) fluorescent stain for 10 min under darkness, then washed with McIlvain buffer (pH 5.5) and dried at room temperature. Plates were observed under a fluorescent microscope with a UV filter. Photographs were taken using a Tmax Kodak film. The chromocentre numbers were determined by checking over 200 resting nuclei per sample $(n=100$ individuals). The chromocentre numbers of $\mathrm{F}_{1} A$. franciscana/A. persimilis laboratory hybrids, produced by the procedure described in Gajardo et al. (2001), were also determined.

Basic statistics, as well as the degree of clustering of the populations, were computed using the STATISTICA package (Statsoft, version 1998). The cluster analysis is based on Euclidean distances, i.e. the actual geometric distances or dissimilarities between chromocentre numbers in a multidimensional space.

\section{Results}

Figure 1 depicts the mean chromocentre numbers in samples of $A$. persimilis $(2 \mathrm{n}=44)$ and $A$. franciscana. $(2 \mathrm{n}=42$, unless otherwise indicated). Mean chromocentre number ranged widely from 0 to a maximum of 17.7, and in many comparisons the range of the variation overlaps considerably between populations. On the whole, variation among samples is, however, greater than within samples (ANOVA, $F_{(19,580)} 191, P<0.001$ ) indicating heterogeneity among populations. Nonetheless, the previously assumed ascription of populations to either A. persimilis or A. franciscana is confirmed by a Tukey multiple range analysis. Both species form relatively homogeneous groups at opposite ends of Fig. 1, $A$. persimilis showing very low $(<3)$ average chromocentre numbers whilst higher numbers $(>5)$ are characteristically seen in A. franciscana. In between, an array of $A$. franciscana populations (some of which fall significantly outside the previously established lower range for the species), account for a a sort of steady transition from lower to higher chromocentre numbers. Interestingly, the laboratory-produced hybrid offspring between $A$. franciscana and $A$. persimilis, SFB/BAI (preliminary results) exhibits chromocentre numbers (Fig. 1) intermediate between those of the parental species. Moreover, 


\begin{tabular}{|c|c|c|}
\hline Country & Location & $\begin{array}{l}\text { Abbreviation } \\
\text { or Batch no. }\end{array}$ \\
\hline 1 USA, CA & San Francisco Bay & 1258 \\
\hline 2 Bahamas & Long Island & 271 \\
\hline 3 Neth. Antilles & Curacao & 502 \\
\hline 4 Venezuela & Tucacas & 218 \\
\hline \multirow{3}{*}{5 Ecuador } & Pacoa & 472 \\
\hline & San Pedro (salt operation) & SPE \\
\hline & Unknown & $\mathrm{ECU}$ \\
\hline \multirow[t]{4}{*}{6 Peru } & Piura & 381 \\
\hline & Unknown & PER \\
\hline & Chilca & $\mathrm{CHI}$ \\
\hline & Casma & CAS \\
\hline \multirow[t]{3}{*}{7 Brazil } & Macau & 202 \\
\hline & Cabo Frío & 1096 \\
\hline & Río Grande do Norte & 322 \\
\hline \multirow[t]{6}{*}{8 Chile } & Pichilemu & $\mathrm{PCH}$ \\
\hline & Salar de Atacama & SAT \\
\hline & Los Vilos & LVI \\
\hline & Convento & $\mathrm{CON}$ \\
\hline & Llamara & LLA \\
\hline & Torres del Paine & TPA \\
\hline \multirow[t]{6}{*}{9 Argentina } & Hidalgo & HID \\
\hline & Colorada chica & 1256 \\
\hline & Buenos Aires province & 1430 \\
\hline & Buenos Aires & 1321 \\
\hline & Buenos Aires & 1393 \\
\hline & Río Negro & 1150 \\
\hline
\end{tabular}

Table 1 Artemia populations used in this study. Populations 1-4 are from the north, and populations 5-9 are from the south of the equator

†ARC classification; populations from Laguna Hidalgo (HID), Argentina, and Casma (CAS), Peru, were kindly provided by Prof. F. Amat and Mr M. Luján, respectively.

populations from the northern hemisphere and northern South America (Ecuador, Venezuela, Peru) show a (north-south) cline of chromocentre number towards the equator (see inset in Fig. 1), and the chromocentres are less fluorescent than those typically seen in $A$. franciscana. This pattern is then reversed towards southern latitudes, and notably, the highest chromocentre frequency is observed in the Chilean population from Torres del Paine (located below $52^{\circ} \mathrm{S}$ ).

The clustering of populations resulting from similarities and/or dissimilarities between chromocentre numbers, shown in Fig. 2, confirms the differences between the two species but also intraspecific heterogeneity. As expected, most populations group as A. franciscana, though in different clusters. Three populations, two from northern Chile (SAT, PCH) and one from Ecuador (SPE, salt operation) fall within the $A$. persimilis group.

\section{Discussion}

Despite the fact that studies on Artemia speciation have considered a wide range of traits, the phylogeny of the genus is far from being established (Badaracco et al.,
1995), and in particular very little is known with regard to the relationship between closely related species. Studies have focused on morphology (Amat, 1980; Gajardo et al., 1998), cytogenetics (Barigozzi, 1974, 1980; Barigozzi et al., 1984; Abatzopoulos et al., 1987; Colihueque \& Gajardo, 1996); protein polymorphism (Abreu-Grobois \& Beardmore, 1982; Gajardo \& Beardmore, 1989, 1993; Pilla \& Beardmore, 1994; Gajardo et al., 1995, 1999), mitochondrial (Perez et al., 1994) and nuclear DNA traits (Badaracco et al., 1987, 1995; Sun et al., 1999).

This population-orientated study of two New World sibling species has important implications for Artemia evolutionary biology. Firstly, it confirms the genetic differentiation between $A$. persimilis and $A$. franciscana (Fig. 2), validating chromocentre numbers as a reliable indicator of speciation. Secondly, it supports the current distribution hypothesis stating that $A$. persimilis is a geographically restricted species (only found in Argentina). The very low chromocentre numbers characteristic of this species are shared by Old World species such as A. salina (Barigozzi, 1980), hence confirming the primitive status of the species, whereas $A$. franciscana 


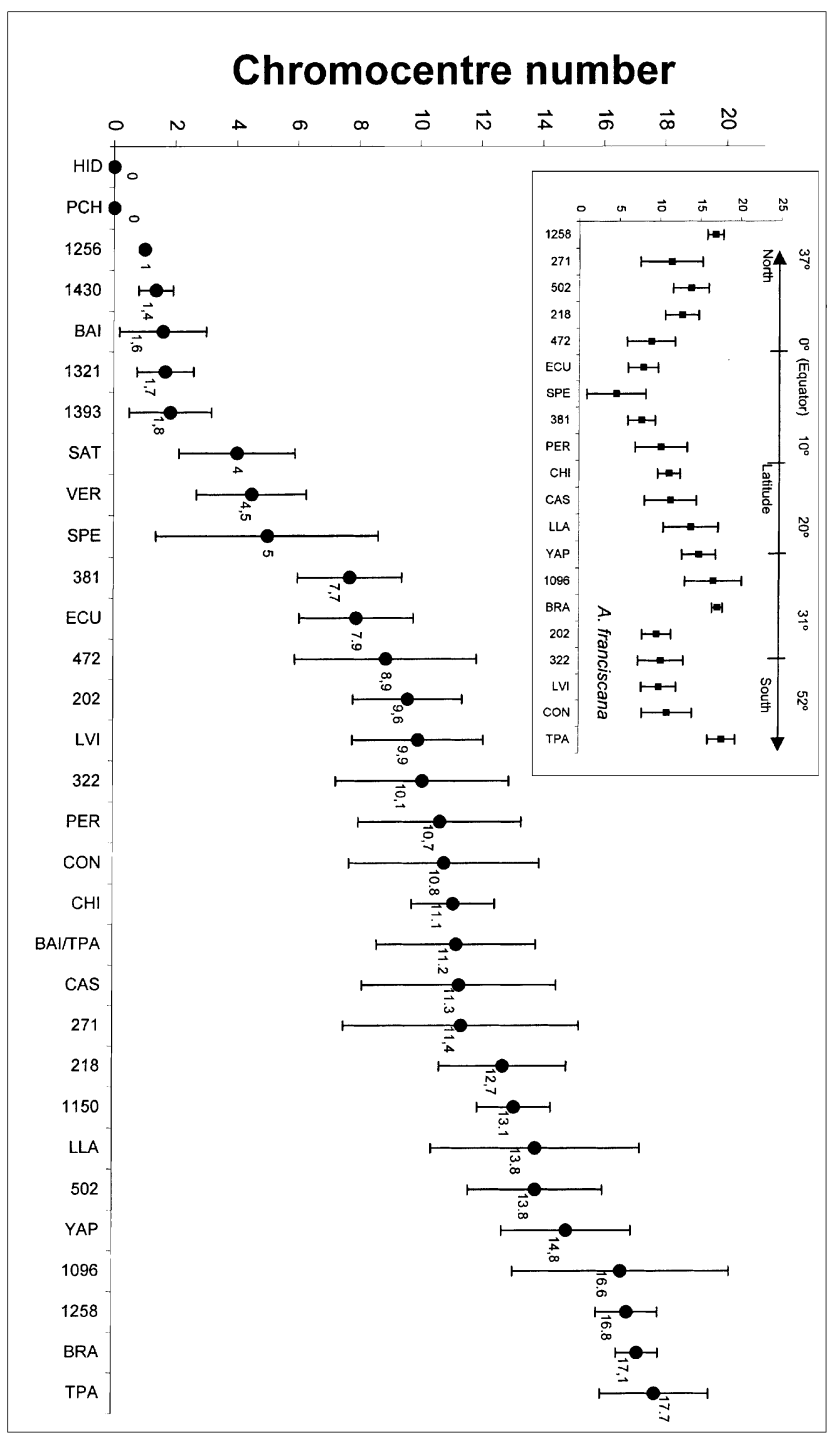

Fig. 1 Variation in mean chromocentre number in populations of Artemia persimilis and A. franciscana in ascending order of mean number. Chromocentre frequency in relation to latitude is also depicted for the $A$. franciscana populations (inset). Code and population abbreviations as in Table 1.

seems to show a derived state. At the same time though, the chromocentre data place the Torres del Paine population from Chile (reportedly A. persimilis according to recently published allozyme (Gajardo et al., 1999) and morphological data (De los Rios \& Zuñiga, 2000)) closer to A. franciscana (see Figs 1 and 2). Likewise, some populations from Chile and Ecuador cluster within the $A$. persimilis range. Last but not least, the clinal decrease and increase, respectively, in chromocentre number in $A$. franciscana found both north and south of the equator points to the need to examine the correlation of chromocentre frequency with latitude.

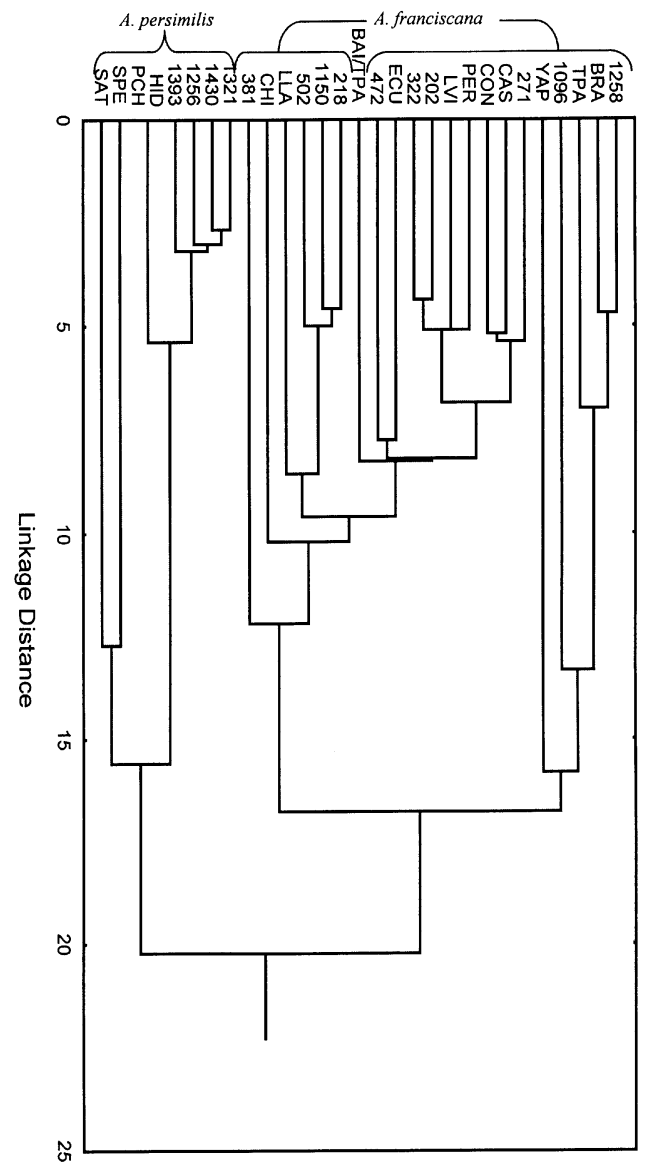

Fig. 2 Clustering of 29 Artemia populations based on the Euclidean distance (raw data) between mean chromocentre numbers.

Similarly, the types of environment encountered by Artemia at different latitudes (not yet well evaluated) require further study.

Heterochromatin represents the transcriptionally silent component (as opposed to euchromatin) of the genome of many animals. Differences in both numbers and staining pattern observed for Artemia in this work could indicate chromosome reorganization, reflecting heterochromatin protein modification between the species, or differential amounts of repetitive DNA, or both of these. The function of satellite DNA associated to chromocentres is unclear, although work done in other species suggests a role in the structural organization of the nucleus. For instance, change in heterochromatin conformation in Drosophila can dramatically affect (i.e. silence) wild type genes, hence affecting the phenotype. Furthermore, recent evidence showing than noncoding DNA is subject to selective elimination (see review in Hartl, 2000) gives support to those who had previously considered heterochromatin as a dynamic element during speciation (Barigozzi et al., 1987) and

(C) The Genetics Society of Great Britain, Heredity, 87, 172-177. 
even directly adaptive to certain types of habitats and ecological niches (White, 1978).

The north-south cline in chromocentre number seen in A. franciscana (inset, Fig. 1) and its actual wider distribution, as compared to other Artemia species, might be an indication of this adaptive relevance. In addition to the chromosomal reorganization brought about by the amplification of certain repetitive sequences in Artemia, differences in overall genome size are also likely to be a target of selection (Hartl, 2000).

The seemingly puzzling situation with the Chilean population from Torres del Paine is not, however, inexplicable, as the two sets of data do not necessarily provide congruent evolutionary information, since they are likely to reflect different characteristics of genome organization. Individuals of mixed ancestry (sharing A. persimilis and A. franciscana characteristics in a single genome), or hybrid types, are likely to be found in novel habitats, unlike the parental ones. Indeed, the 'Hybrid superiority' model put forward by Arnold (1997), which could be applied to this Artemia population, belongs to the environment-dependent or selection-gradient concept, and predicts that hybrid zones may often be found in transitional regions. The area of Torres del Paine is ecologically transitional in many respects. It is located below latitude $58^{\circ} \mathrm{S}$ in Chilean Patagonia in a semiarid and humid area exhibiting high environmental variation. These are unusual conditions compared to those described for Artemia in general and for A. franciscana in particular (see Gajardo et al., 1992, 1999). Although quite geographically separated from other Artemia sites in Chile, the chances for gene flow across the Andes (the natural barrier between Chile and Argentina) are greater at this latitude, where the Andes are lower. Under such circumstances it would not be surprising to find a hybrid Artemia population exhibiting characteristics of both parental species. If $A$. persimilis is expanding its range of distribution, introgression might be possible, particularly considering the current rate of either intentional or natural dissemination of cysts. The ongoing evaluation of chromocentre frequency in laboratory-produced back-crosses will enable us to assess the likelihood of hybridization in nature.

\section{Acknowledgements}

This work is paper LXII of the International Interdisciplinary Study on Artemia populations co-ordinated by the laboratory of Aquaculture \& Artemia Reference Centre, University of Ghent, Belgium. We gratefully acknowledge the technical help of Margarita Parraguéz. Financial support was provided by the Ministry of the Flemish Community, Science Division (Grant No. BIL98/03), and Fondecyt (1940812), Chile.

\section{References}

ABATZOPOULOS, T.J., TRIANTAPHYLLIDIS, C.D. AND KASTRITSIS, C.D. 1987. Preliminary studies on some Artemia populations from northern Greece. In: Sorgeloos, P., Bengtson, D. A., Declair, W. and Jaspers, B. (eds) Artemia Research and its Application, Vol. 1, pp. 107-114. Universa Press, Wetteren.

ABREU-Grobois, F. A. 1987. A review of the genetics of Artemia. In: Sorgeloos, P., Bengtson, D. A., Declair, W. and Jaspers, B. (eds) Artemia Research and its Application, Vol. 1, pp. 61-99. Universa Press, Wetteren.

ABreU-Grobois, F. A. AND BEARDMORE, J. A. 1982. Genetic differentiation of the brine shrimp Artemia. In: Barigozzi, C. (ed.) Mechanisms of Speciation, pp. 345-376. Alan R. Liss, New York.

AMAT, D. F. 1980. Differentiation in Artemia strains from Spain. In: Persoone, G., Sorgeloos, P., Roels, O. and Jaspers, E. (eds) The Brine Shrimp Artemia, Vol. 1, pp. 19-40. Universa Press, Wetteren.

ARNOLD, M. L. 1997. Natural Hybridization and Evolution. Oxford University Press, Oxford.

BADARACCO, G., BARATELLI, L., GINELLI, E., MENEVERI, R. ET AL. 1987. Variations in repetitive DNA and heterochromatin in the genus Artemia. Chromosoma, 95, 71-75.

BADARACCO, G., BELlORINI, M. AND LANDSHERGER, N. 1995. Phylogenetic study of bisexual Artemia using random amplified polymorphic DNA. J. Mol. Evol, 41, 150-154.

BARIGOZZI, C. 1974. Artemia: a survey of its significance in genetic problems. Evol. Biol., 7, 221-252.

BARIGOzZI, C. 1980. Genus Artemia: Problems of systematics. In: Persoone, G., Sorgeloos, P., Roels, O. and Jaspers, E. (eds) The Brine Shrimp Artemia, Vol. 1, pp. 147-153. Universa Press, Wetteren.

BARIGOZZI, C., BADARACCO, G., PLEVANI, P., BARATELLI, L. ET AL. 1984. Heterochromatin in the genus Artemia. Chromosoma, 90, 332-337.

BARIGOZZI, C., VALSANINI, P., GINELLI, B., BADARACCO, G. ET $A L$. 1987. Further data on repetitive DNA and speciation in Artemia. In: Sorgeloos, P., Bengtson, D. A., Declair, W. and Jaspers, E. (eds) Artemia Research and its Applications, Vol. 1, pp. 103-105. Universa Press, Wetteren.

BEARDMORE, J. A. AND ABREU-GRobois, F. A. 1983. Taxonomy and evolution in the brine shrimp Artemia. In: Oxford, G. S. and Rollinson, D. (eds) Protein Polymorphism: Adaptive and Taxonomic Significance, pp. 153-164. Academic Press, London.

BROWNE, R. A. AND BowEN, S. T. 1991. Taxonomy and population genetics of Artemia. In: Browne, R. A., Sorgeloos, P. and Trotman, C. N. A. (eds) Artemia Biology, pp. 221-235. CRC Press, Boca Raton.

COHEN, R. G., AMAT, F., HONTORIA, F. AND NAVARRo, J. C. 1999. Preliminary characterization of some Argentinean Artemia populations from La Pampa and Buenos Aires provinces. Int. J. Salt Lake Res., 8, 329-340.

COLIHUEQue, N. AND GAJARdo, G. 1996. Chromosomal analysis in Artemia populations from South America. Cytobios, 88, 141-148.

(C) The Genetics Society of Great Britain, Heredity, 87, 172-177. 
DE LOS RIOS, P. AND ZUÑIGA, O. 2000. Biometric comparison of the frontal knob in American populations of Artemia (Anostraca, Artemiidae). Rev. Chil. Hist. Nat., 73, 31-38.

GAJARDO, G. M. AND BEARDMORE, J. A. 1989. Ability to switch reproductive mode in Artemia is related to maternal heterozygosity. Mar. Ecol. Prog. Ser., 55, 191-195.

GAJARDO, G. M. AND BEARDMORE, J. A. 1993. Electrophoretic evidence suggests that the Artemia found in the Salar de Atacama, Chile, is A. franciscana Kellogg. Hydrobiologia, 257, 65-71.

GAJARDO, G. M., WILSON, R. AND ZUÑIGA, O. 1992. Report on the occurrence of Artemia in a saline deposit of the Chilean Andes. Crustaceana, 62, 169-174.

GAJARDO, G.M., CONCEICAO, D. A., WEBER, L. AND BEARDMORE, J.A. 1995. Genetic variability and interpopulational differences in Artemia strains from South America. Hydrobiologia, 302, 21-29.

GAJARDo, G., COLIHUEQUe, N., PARRAGUez, M. AND SORGEloOs, P. 1998. International study on Artemia. LVIII. Morphologic differentiation and reproductive isolation of Artemia populations from South America. Int. J. Salt Lake Res., 7, 133-151.

GAJARDO, G., MERCADO, C., BEARDMORE, J. A. AND SORGELOOS, P. 1999. International study on Artemia. LX. Allozyme data suggest that a new Artemia population in southern Chile $\left(50^{\circ} 29^{\prime} \mathrm{S} ; 73^{\circ} 45^{\prime} \mathrm{W}\right)$ is $A$. persimilis. Hydrobiologia, 405, $117-123$.
GAJARDO, G., PARRAGUEZ, M., BEARDMORE, J. A. AND SORGELOOS, P. 2001. Reproduction in the brine shrimp Artemia: evolutionary relevance of laboratory cross-fertility tests. J. Zool., 253, 25-32.

HARTL, D. L. 2000. Molecular melodies in high and low C. Nature Rev., 1, 145-149.

NEI, M. 1978. Estimation of average heterozygosity and genetic distance from a small number of individuals. Genetics, 89, 583-590.

PEREZ, M. L., VALVERde, J. R., BATUECAS, B., AMAT, F. ET $A L$. 1994. Speciation in the Artemia genus: Mitochondrial DNA analysis of bisexual and parthenogenetic brine shrimp. J. Mol. Evol., 38, 156-168.

PILlA, E. J. S. AND BEARDMORE, J. A. 1994. Genetic and morphometric differentiation in Old World bisexual species of the brine shrimp Artemia. Heredity, 73, 47-56.

SUN, Y., ZHONG, Y. C. H., SONG, W. Q., ZHANG, R. S. ET AL. 1999. Detection of genetic relationships among four Artemia species using randomly amplified polymorphic DNA (RAPD). Int. J. Salt Lake Res., 8, 139-147.

TRIANTAPHYLLIDIS, G. V., ABATZOPOULOS, T. J. AND SORGELOOS, P. 1998. Review of the biogeography of the genus Artemia (Crustacea, Anostraca). J. Biogeogr., 25, 213-226.

white, M. J. D. 1978. Modes of Speciation. W. H. Freeman, San Francisco. 